\title{
Inhibitory effects of SEL201 in acute myeloid leukemia
}

\author{
Ewa M. Kosciuczuk ${ }^{1,2,3, *}$, Aroop K. Kar ${ }^{1,4, *}$, Gavin T. Blyth ${ }^{1,2}$, Mariafausta Fischietti ${ }^{1,2}$, \\ Sameem Abedin ${ }^{1,2,5}$, Alain A. Mina ${ }^{1,2}$, Rebekah Siliezar ${ }^{1}$, Tomasz Rzymski, ${ }^{6}$ Krzysztof \\ Brzozka $^{6}$, Elizabeth A. Eklund ${ }^{1,2,3}$, Elspeth M. Beauchamp ${ }^{1,2,3}$, Frank Eckerdt ${ }^{1,7}$, Diana \\ Saleiro ${ }^{1,2}$ and Leonidas C. Platanias ${ }^{1,2,3}$ \\ ${ }^{1}$ Robert H. Lurie Comprehensive Cancer Center of Northwestern University, Chicago, Illinois, USA \\ ${ }^{2}$ Division of Hematology-Oncology, Department of Medicine, Feinberg School of Medicine, Northwestern University, Chicago, \\ Illinois, USA \\ ${ }^{3}$ Department of Medicine, Jesse Brown Veterans Affairs Medical Center, Chicago, Illinois, USA \\ ${ }^{4}$ Division of Hematology/Oncology/Stem Cell Transplantation, Department of Pediatrics, Ann and Robert H. Lurie Children's \\ Hospital of Chicago, Chicago, Illinois, USA \\ ${ }^{5}$ Division of Hematology and Oncology Department of Medicine Medical College of Wisconsin, Milwaukee, Wisconsin, USA \\ ${ }^{6}$ Ryvu Therapeutics, Kraków, Poland \\ ${ }^{7}$ Department of Neurological Surgery, Feinberg School of Medicine, Northwestern University, Chicago, Illinois, USA \\ *These authors contributed equally to this work
}

Correspondence to: Leonidas C. Platanias, email: I-platanias@northwestern.edu

Keywords: acute myeloid leukemia; MNK; elF4E; kinase inhibitor; SEL20 1

Received: October 17, $2019 \quad$ Accepted: December 02, $2019 \quad$ Published: December 24, 2019

Copyright: Kosciuczuk et al. This is an open-access article distributed under the terms of the Creative Commons Attribution License 3.0 (CC BY 3.0), which permits unrestricted use, distribution, and reproduction in any medium, provided the original author and source are credited.

\section{ABSTRACT}

MAPK interacting kinase (MNK), a downstream effector of mitogen-activated protein kinase (MAPK) pathways, activates eukaryotic translation initiation factor 4E (eIF4E) and plays a key role in the mRNA translation of mitogenic and antiapoptotic genes in acute myeloid leukemia (AML) cells. We examined the antileukemic properties of a novel MNK inhibitor, SEL201. Our studies provide evidence that SEL201 suppresses eIF4E phosphorylation on Ser209 in AML cell lines and in primary patient-derived AML cells. Such effects lead to growth inhibitory effects and leukemic cell apoptosis, as well as suppression of leukemic progenitor colony formation. Combination of SEL201 with 5'-azacytidine or rapamycin results in synergistic inhibition of AML cell growth. Collectively, these results suggest that SEL201 has significant antileukemic activity and further underscore the relevance of the MNK pathway in leukemogenesis.

\section{INTRODUCTION}

Acute myeloid leukemia (AML) is an aggressive hematological malignancy with relatively limited therapeutic options [1]. Abnormal activation of multiple signalling pathways, including mitogen-activated protein kinase (MAPK) pathways, is key in the pathogenesis and pathophysiology of AML. These pathways regulate different cellular processes including leukemic cell proliferation and survival in response to a variety of signals [2-5]. MAPK-interacting kinases 1 and 2 (MNK1/2) are downstream effectors of MAPK pathways and regulate multiple cellular processes through phosphorylation/ activation of the eukaryotic translation initiation factor 4E (eIF4E) [6-9], a key component of the translationinitiation complex $[10,11]$. MNK1/2 phosphorylation of eIF4E at serine 209 triggers increased mRNA translation of mitogenic mRNAs that promote proliferation, cell cycle progression, and pro-survival processes [12-15]. eIF4E has been found to be overexpressed in a wide variety of human malignancies [16-20] and eIF4E phosphorylation on serine 209 is strongly associated with its transforming capacity $[21,13]$. However, neither MNK activity, nor the phosphorylation of eIF4E appear to be essential for 
normal development $[12,22,23]$. Given that MNKmediated eIF4E phosphorylation strongly contributes to tumorigenesis, lymphomagenesis, and tumor metastasis while being dispensable for development, pharmacological MNK1/2 inhibition may represent an attractive strategy for the treatment of leukemias $[24,21,12]$.

Recently, a new ATP-competitive inhibitor of MNK1/2, SEL201, has been reported to selectively inhibit MNK1 and MNK2 activity, with a half maximal inhibitory concentration $\left(\mathrm{IC}_{50}\right)$ of $10.8 \mathrm{nM}$ and $5.4 \mathrm{nM}$, respectively, in in vitro kinase assays [25]. Importantly, SEL201 was shown to be orally bioavailable, safe and well tolerated in mice [26]. Moreover, SEL201 showed potent antitumor and anti-metastatic effects using KIT-mutant melanoma and breast cancer in in vitro and in vivo models [25, 26]. In the current study, we examined the antileukemic properties of SEL201 using AML models. We provide evidence that SEL201 suppresses eIF4E phosphorylation on Ser209 in AML cells and such effects appear to result in enhanced cellular apoptosis, and growth inhibitory responses. Notably, combination of SEL201 with 5'-azacytidine and rapamycin resulted in synergistic anti-leukemic effects in vitro.

\section{RESULTS}

In initial studies, we examined the effects of SEL201 on eIF4E phosphorylation in AML cells. Treatment of the MV4-11, MM6 or U937 cell lines with SEL201 reduced phosphorylation of eIF4E on Ser209 in a dose and timedependent manner (Figure 1A-1C). Similar results were obtained when the effects of SEL201 on patient-derived primary AML cells were determined (Figure 1D and 1E). To define the functional relevance of inhibition of eIF4E phosphorylation by SEL201, we next performed cellular viability assays using AML cells. SEL201 treatment suppressed the cellular viability of MV4-11 and MM6 cells with $\mathrm{IC}_{50}$ values of $0.4 \mu \mathrm{M}$ and $1.8 \mu \mathrm{M}$, respectively (Figure $1 \mathrm{~F}$ and $1 \mathrm{G}$ ). Additionally, we evaluated the anti-leukemic effects of SEL201 on primitive leukemic progenitors in clonogenic assays in methylcellulose. SEL201 treatment resulted in significant inhibition of colony formation (CFU-L) derived from different leukemic lines, as well as in primary leukemic precursors from AML patients (Figure 2A-2D). On the other hand, SEL201 showed no suppressive effects on normal bone marrow (BM) derived $\mathrm{CD} 34^{+}$cells in myeloid colony formation (CFU-GM) assays (Figure 2E).

In addition to blocking tumor cell viability and proliferation, induction of programmed cell death (apoptosis) is an important effect of many antitumor agents [27]. We examined the pro-apoptotic functions of SEL201 in MV4-11 and MM6 cells using flow cytometry analysis. SEL201 treatment significantly increased the fraction of Annexin- $\mathrm{V}$ positive cells in a dose and time-dependent manner, compared to vehicle-treated cells (Figure 3). To further corroborate the induction of apoptosis by SEL201 in AML cells, we assessed the cleavage/activation of the apoptotic markers PARP and caspase 3 by immunoblotting. Treatment of MV4-11 cells with SEL201 resulted in cleavage of both caspase 3 and PARP, consistent with induction of apoptosis (Figure 3B).

Many patients with AML either do not respond to therapy or often relapse and develop resistance mechanisms to currently used therapies [28, 29], underscoring the need for the development of new treatments for AML patients. Targeting the mTOR and MNK-eIF4E pathways may provide important new opportunities for new cancer therapeutic approaches [30-33]. We evaluated the antitumor combinatorial effect of SEL201 with rapamycin that inhibits the activation of mammalian target of rapamycin complex 1 (mTORC1) [34]. Combination of SEL201 with rapamycin treatment resulted in synergistic inhibition of cell viability of MV4-11 cells $(\mathrm{CI}=0.20)$ and $\mathrm{U} 937$ cells $(\mathrm{CI}=0.35)$ (Figure 4A). In addition, the combination of SEL201 with rapamycin significantly enhanced the suppressive effects on leukemic progenitor colony formation (CFU-L) from U937 cells in clonogenic assays in methylcellulose (Figure 4B).

In subsequent experiments we examined whether MNK1/2 inhibition by SEL201 could enhance the antileukemic properties of 5'-azacytidine, a hypomethylating agent with major clinical activity in AML and myelodysplastic syndromes (MDS) [35, 36]. The combination of 5'-azacytidine with SEL201 showed a synergistic effect with a CI value of 0.60 for U937 cells, and an additive effect with a CI value of 1.0 for MV4-11 cells (Figure 4C). Additionally, the combination of SEL201 with 5'-azacytidine significantly enhanced inhibition of colony formation (CFU-L) of U937 cells in clonogenic assays in methylcellulose (Figure 4D). To evaluate whether the potent and synergistic antileukemic effects of combinatorial treatment of SEL201 with 5 '-azacytidine correlates with induction of apoptosis, we measured the induction of cellular apoptosis in U937 cells by flow cytometry analysis. We observed a significant increase in Anexin V-positive staining when U937 cells were treated with SEL201 in combination with 5 '-azacytidine, as compared to each drug treatment alone (Figure 4E).

\section{DISCUSSION}

MAPK pathways have been previously shown to be constitutively activated in malignant hematopoietic cells and control malignant cell proliferation, via downstream effectors, including activation of MNKs [37, 38]. When activated, MNKs phosphorylate eIF4E, which drives mRNA translation of pro-tumorigenic proteins, such as BCL-2, survivin, cyclin D1 and c-myc [11, 39]. Previous work has shown that MNK1/2 inhibition might block the 
self-renewal capacity of leukemic cells, without affecting normal progenitor functions [40]. Additionally, eIF4E has been found to be overexpressed in M4/M5 subtypes of AML [41, 42]. Given its involvement in leukemia progression and dispensable role in normal hematopoiesis [40], eIF4E is an attractive therapeutic target in AML. Specific and direct targeting of eIF4E by anti-sense oligonucleotides has previously been used as an eIF4E targeting approach [43]. However, although originally promising, this approach reduced eIF4E expression, but did not substantially improve clinical responses in patients with advanced solid tumors, including colorectal cancer $[44,45]$. Given that phosphorylation of eIF4E is crucial for its oncogenic activity, targeting MNK activity might constitute a better strategy for the treatment of malignancies. In fact, several studies have shown that the

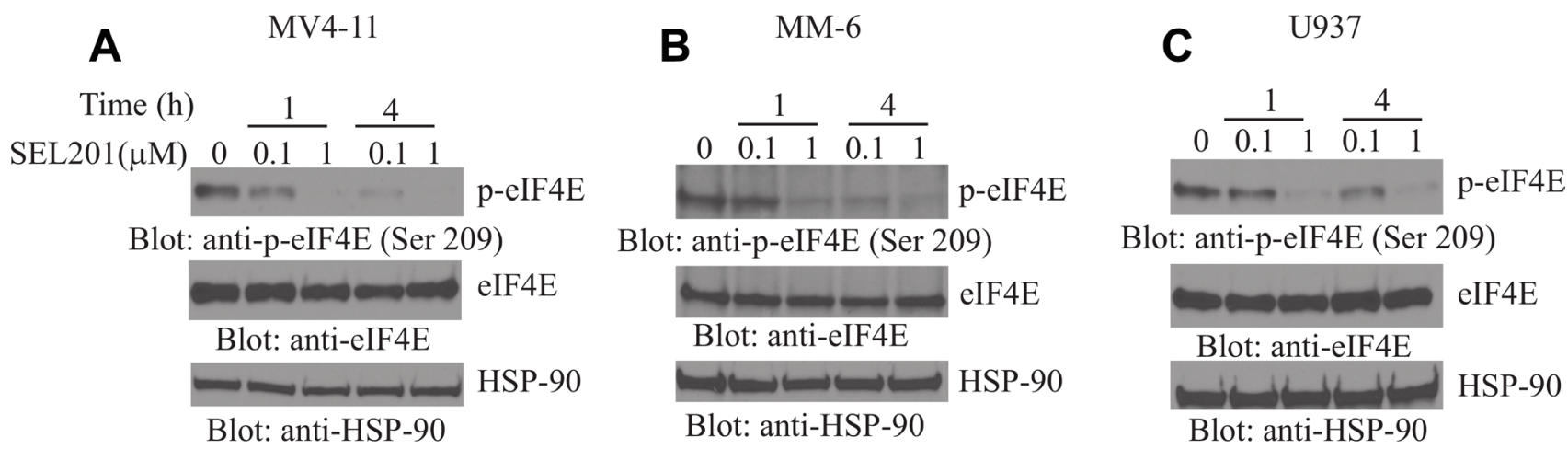

D

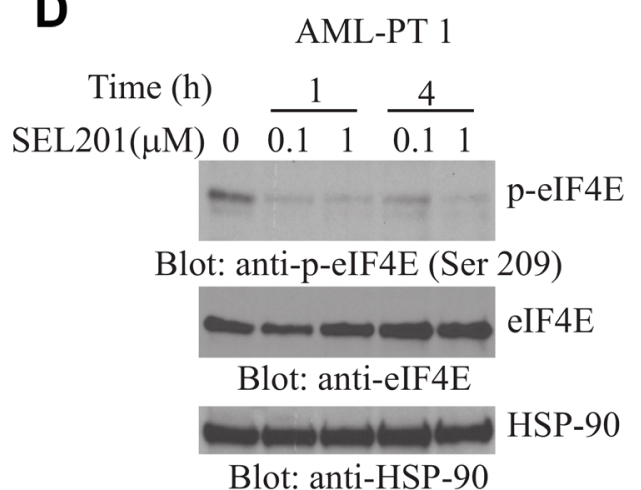

Blot: anti-HSP-90

$\mathbf{F}$

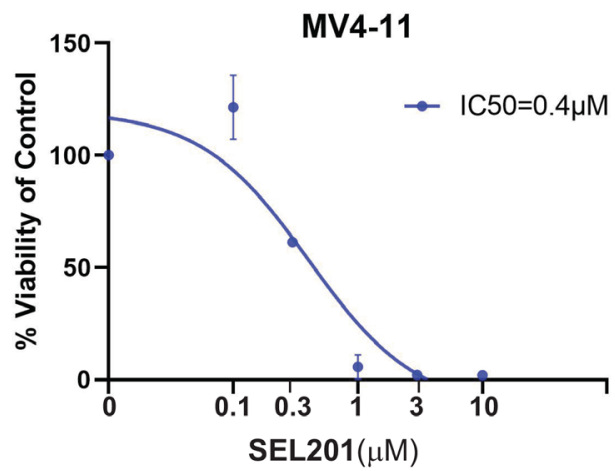

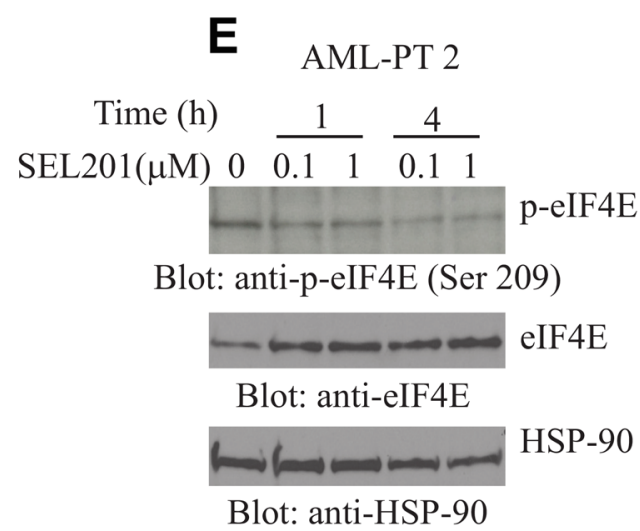

G

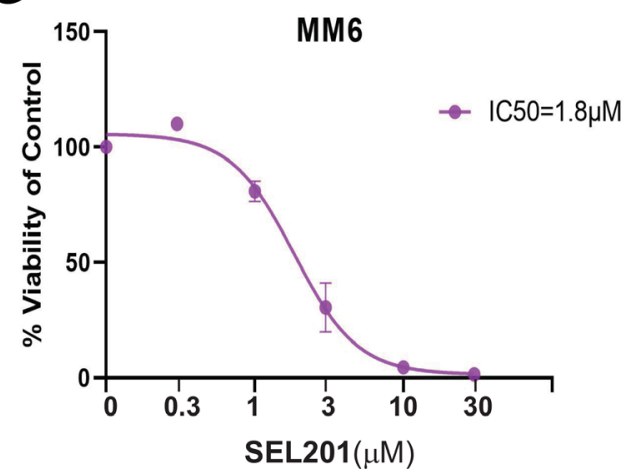

Figure 1: SEL201 suppresses phosphorylation of eIF4E and inhibits cell proliferation in AML. (A) MV4-11, (B) MM6, (C) U937 cells or (D-E) AML patient-derived cells were incubated with SEL201 for 1 hour and 4 hours at final concentrations of either 0.1 or $1 \mu \mathrm{M}$. Equal amount of total cell lysates were resolved by SDS-PAGE. Blots were probed with the indicated antibodies. (F) MV411, (G) MM6 cells were plated in 96 well plates and treated with increasing concentrations of SEL201 for 7 days. Viability was assessed using WST-1 assay. Data are expressed as a percentage of control (DMSO-treated) cells. Shown are the means \pm SE of 3 independent experiments, each done in triplicate, and $\mathrm{IC}_{50}$ values are shown for each cell line. 
oncogenic activity of eIF4E can be targeted by inhibiting MNK1/2-induced phosphorylation of eIF4E at serine 209 in different malignancies, including AML, which leads to potent anti-tumor responses in vitro and in vivo [30, 46-48]. Thus, the selective targeting of this pathway, alone or in combination with other therapies, could be a promising therapy for the treatment of AML.

In the current study, we examined the anti-leukemic effects of SEL201, a novel, orally bioavailable, well tolerated and safe in vivo, small-molecule inhibitor of MNK1/2 activity $[25,26]$. SEL201 has been recently developed and has been reported to inhibit melanoma clonogenicity, cell migration, and metastasis formation [25], and to induce cell cycle arrest, inhibit proliferation and block invasion and metastasis of breast ductal carcinoma in situ [26]. Importantly, SEL201 does not appear to affect proliferation of normal, non-malignant melanocytes [25]. Our studies demonstrate that SEL201 inhibits eIF4E phosphorylation in AML cell lines and primary AML cells, consistent with a direct effect through inhibition of MNK kinase activity. In previous studies blocking eIF4E phosphorylation was shown to suppress mRNA translation of oncogenic genes, leading to inhibition of cancer cells proliferation [26, 46, 47]. In our study, we show that SEL201 suppresses cellular proliferation, viability and clonogenicity in AML. Notably, SEL201 was also found to not suppress the clonogenic capability of normal bone marrow-derived CD34 ${ }^{+}$ progenitor cells. Previous studies have shown that eIF4E activation promotes tumorigenesis by inducing expression of anti-apoptotic proteins, such as MCL-1 and survivin [12, 39, 49]. Consistent with this, we found here that inhibition of eIF4E phosphorylation by SEL201 correlates with induction of apoptosis in AML cells.

Cytarabine, an antimetabolic agent currently used for the treatment of AML, was previously shown to induce phosphorylation of eIF4E on serine 209, which could constitute a potential anti-cancer resistance mechanism activated during administration of this therapy [31]. Consistently, cercosporamide, an anti-fungal agent with MNK inhibitory effects, was shown to enhance the antileukemic effects of cytarabine in AML in vitro and in vivo models [30]. Additionally, ribavirin, an anti-viral guanosine analogue, identified as a direct eIF4E inhibitor,
A

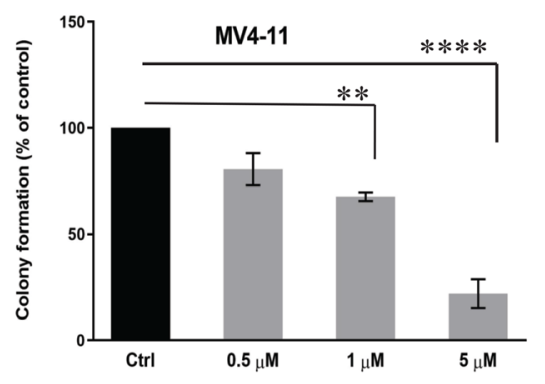

D

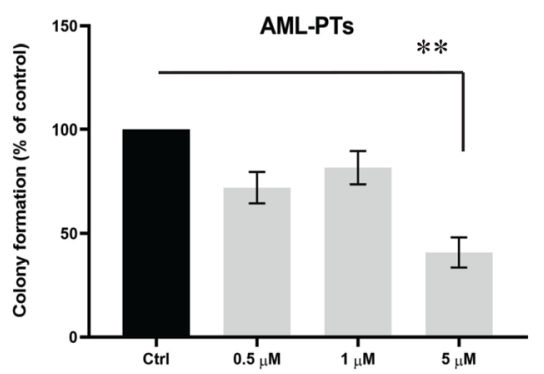

B

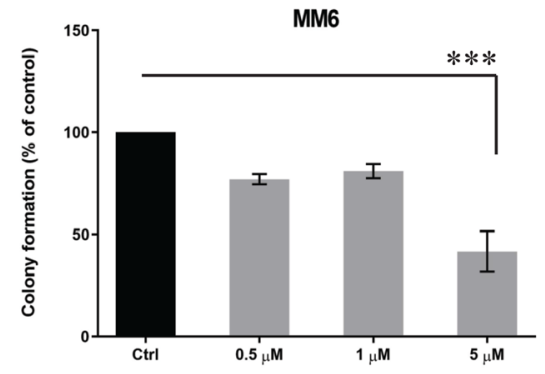

C

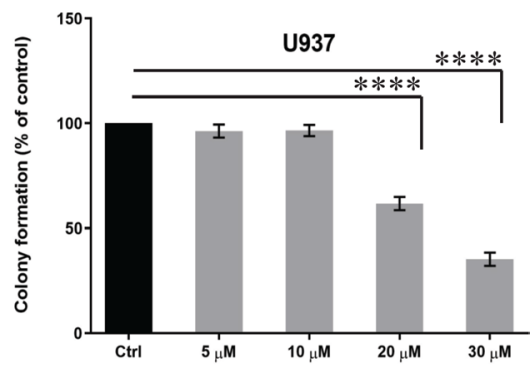

E

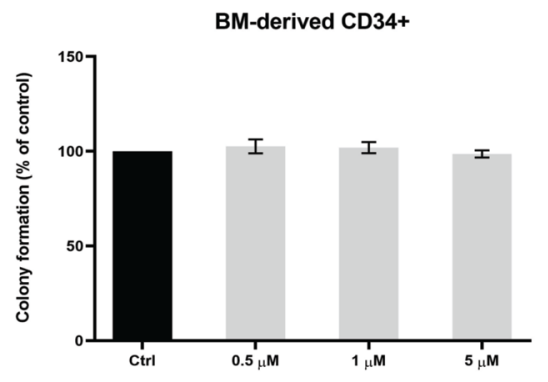

Figure 2: SEL201 exhibits suppressive effects on AML leukemic progenitors, but not on normal hematopoietic progenitors. (A) MV4-11, (B) MM6 and (C) U937 cells were plated in a methylcellulose culture assay system with increasing concentrations of SEL201, as indicated. Data are expressed as percentage of colony formation of control (vehicle-treated) cells, and shown are the means \pm SE of four independent experiments for MV4-11 and U937 and three independent experiments for MM6. (D) The inhibitory effects of SEL201 on primary leukemic precursors from AML patients were assessed in clonogenic assays in methylcellulose. Data are expressed as percentage of colony formation of control (vehicle-treated) cells. Shown are the means \pm SE from four independent experiments, using cells from four different patients with AML. (E) Normal human bone marrow-derived CD34 ${ }^{+}$cells were plated in clonogenic assays in methylcellulose with increasing concentrations of SEL201, and myeloid (CFU-GM) progenitor colony formation was assessed. Data are expressed as percentage of colony formation of control (vehicle-treated) cells and represent means \pm SE of three independent experiments. One-way ANOVA analysis followed by Tukey's test was used to evaluate statistically significant differences: ${ }^{* *} p<0.01,{ }^{* * *} p<0.001,{ }^{* * *} p<0.0001$. 
was shown to enhance the therapeutic effects of cytarabine in a clinical trial involving AML patients [41]. Further, drug inhibition of mTORC1 pathways was also shown to trigger phosphorylation of eIF4E via activation of a negative feedback prosurvival pathway $[30,31]$. Thus, dual inhibition of mTORC1 and MNK-eIF4E pathways might represent an important strategy for the treatment of several types of cancer $[30,31,33,50,51]$. Here, we show that combination of SEL201 with the mTORC1 inhibitor rapamycin exhibits potent antileukemic properties in AML

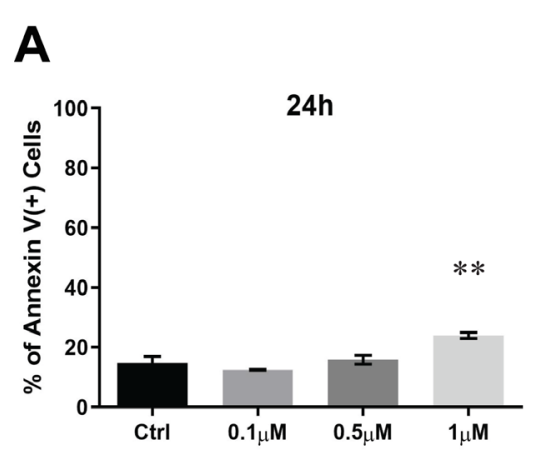

$\underline{\text { MV4-11 }}$
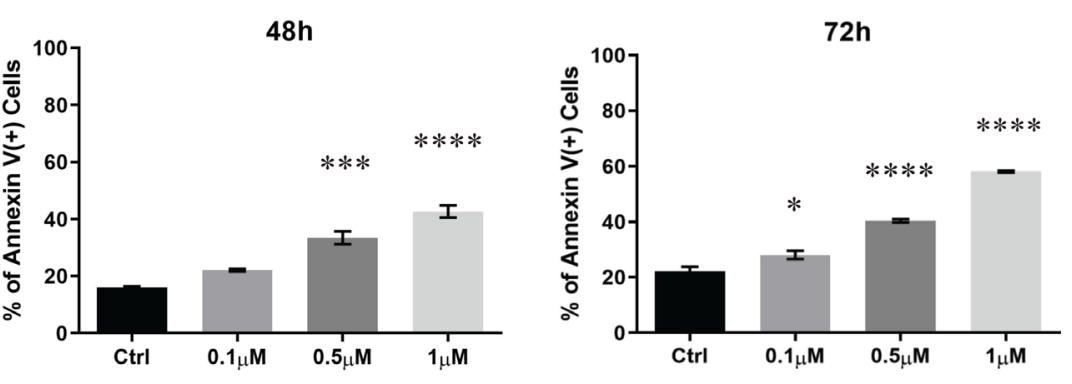

B

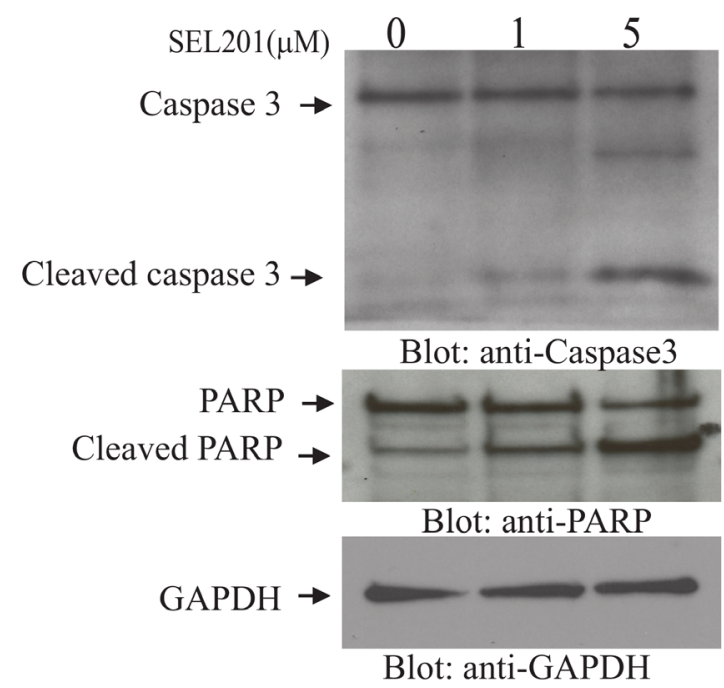

C

$\underline{\text { MM6 }}$

$48 \mathrm{~h}$

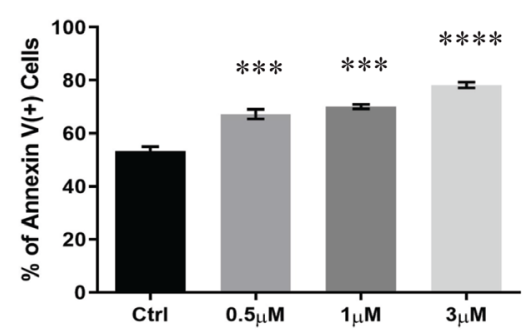

$72 \mathrm{~h}$

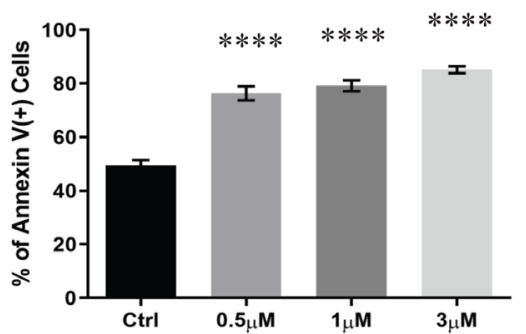

Figure 3: SEL201 induces apoptosis of AML cells. (A) MV4-11 cells were treated with SEL201 at the indicated doses for 24, 48 and 72 hours. The percentage of apoptosis was determined by flow cytometry using Anexin V/DAPI staining. Shown are the means \pm SE of three independent experiments. (B) MV4-11 cells were treated with vehicle or SEL201 at the indicated doses for 24 hours. Whole cell lysates were resolved by SDS-PAGE and immunobloted with the indicated antibodies. (C) MM6 cells were treated with SEL201 at the indicated doses for 48 hours and 72 hours. The percentage of apoptosis was determined using Annexin V/DAPI staining followed by flow cytometry analyses. One-way ANOVA analysis followed by Tukey's test was used to evaluate statistically significant differences between treatments: ${ }^{*} p<0.05,{ }^{* *} p<0.01,{ }^{* * *} p<0.001,{ }^{* * * *} p<0.0001$. 
cells lines and primary AML cells. Additionally, we also determined the effects of SEL201 with 5'-azacytidine. Azacitidine (5'-azacytidine) is a clinically approved hypomethylating agent that inhibits DNA methylation of tumor suppressor genes, enhancing their transcription, and has shown significant clinical benefits in patients with myeloid malignancies $[35,51,52]$. Our data show that combination of SEL201 with 5'-azacytidine results

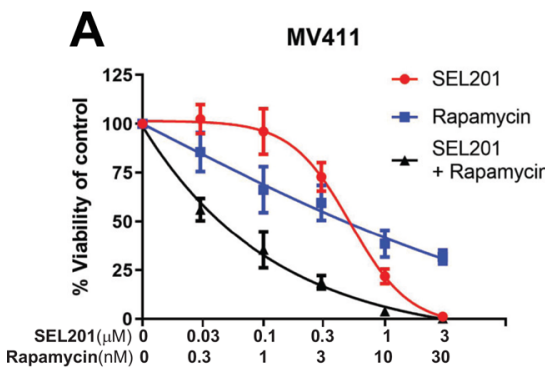

C

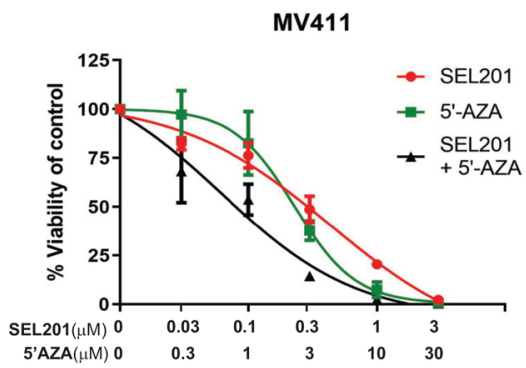

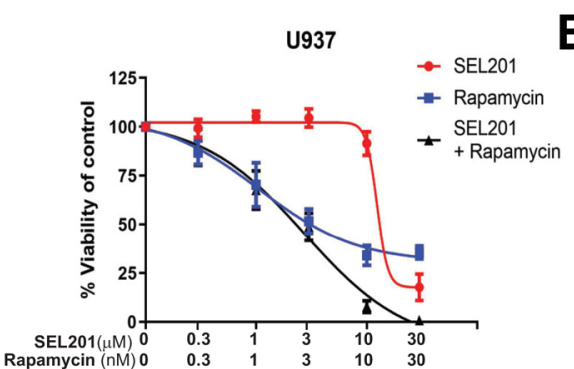

B

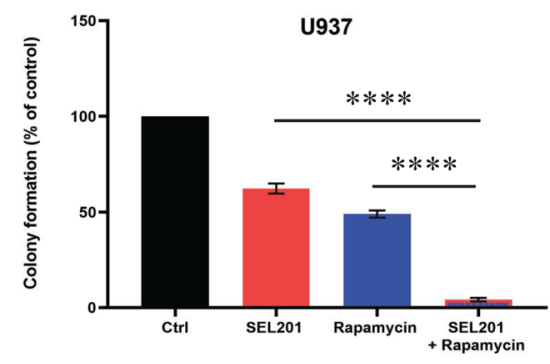

D
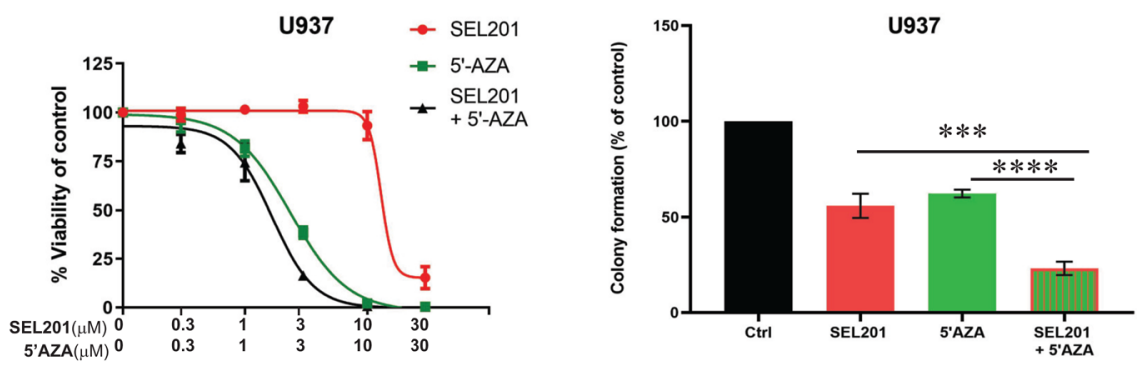

\section{$\underline{\mathbf{U 9 3 7}}$}

$\mathbf{E}$

$48 h$

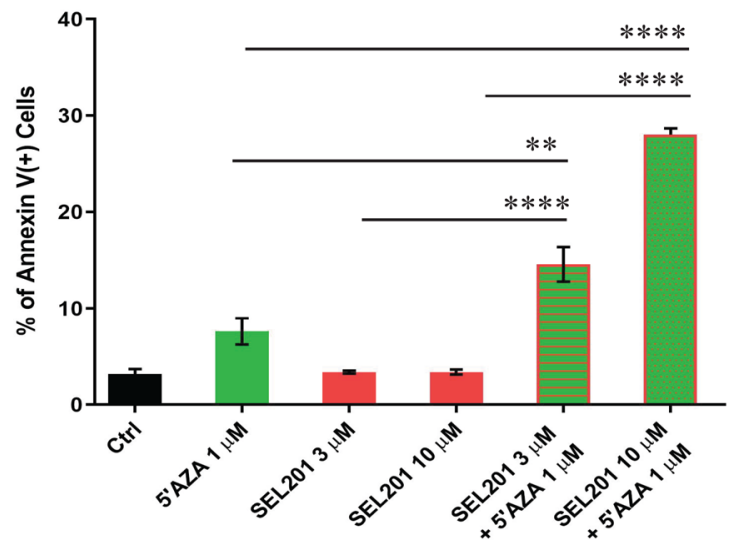

$72 \mathrm{~h}$

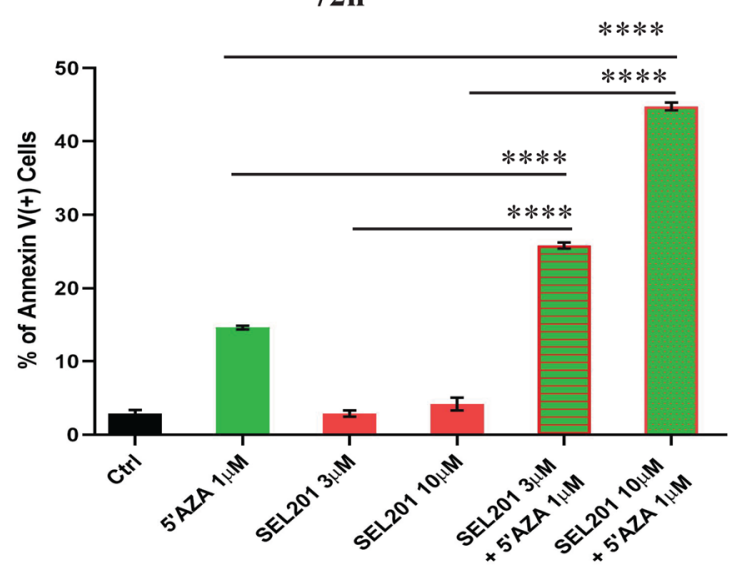

Figure 4: Enhanced antileukemic effects of MNK inhibition combined with rapamycin or 5'-azacytidine. (A) MV4-11 and U937 cells were plated in 96 well plates and treated with SEL201 and/or rapamycin for 4 days. Viability was assessed using WST-1 assay. Data are expressed as percentage of vehicle-treated cells (control). Shown are the means $\pm \mathrm{SE}$ of five independent experiments for MV4-11 and four for U937. (B) U937 cells were plated in methylcellulose culture assay system in the presence of SEL201 and rapamycin alone or in combination, as indicated. Data are expressed as percentage of colony formation of control (vehicle-treated) cells, and shown are the means \pm SE of four independent experiments. (C) MV4-11 and U937 cells were plated in 96 well plates and treated with SEL201 and 5'-azacytidine alone and in combination, as indicated, for 4 days. Viability was assessed using a WST-1 assay. Data are expressed as a percentage of vehicle-treated cells (control). Shown are the means \pm SE of four independent experiments. (D) U937 cells were plated in methylcellulose culture assay system in the presence of SEL201 and 5'-azacytidine alone or in combination, as indicated. Data are expressed as percentage of colony formation of control (vehicle-treated) cells, and represent means $\pm \mathrm{SE}$ of four independent experiments. (E) U937 cells were treated with SEL201 or 5'-azacytidine alone or in combination for 48 hours and 72 hours, as indicated. The percentage of apoptosis was determined using Annexin V/DAPI staining followed by flow cytometry analyses. Shown are means \pm SE of three independent experiments. One-way ANOVA analysis followed by Tukey's test was used to evaluate statistically significant differences between treatments: ${ }^{* *} p<0.01,{ }^{* * *} p<0.001,{ }^{* * * * *} p<0.0001$. 
in synergistic inhibition of leukemic cell viability and induction of apoptosis of U937, TP53 mutated, cells. In another study, ribavirin treatment was shown to increase 5 -azacytidine-induced suppression of colony formation of primary AML specimens [53]. In conclusion, our study establishes that SEL201 has antileukemic properties against AML progenitor cells, and further supports the concept of MNK pathways as therapeutic targets in AML.

\section{MATERIALS AND METHODS}

\section{Cells and reagents}

U937 cells were grown in RPMI 1640 medium with $10 \%$ fetal bovine serum (FBS) and antibiotics. MV4-11 cells were cultured in IMDM medium with 10\% FBS and antibiotics. MM6 cells were grown in RPMI 1640 medium supplemented with 10\% FBS, $10 \mu \mathrm{g} / \mathrm{ml}$ human insulin, $1 \mathrm{mM}$ sodium pyruvate, $1 \mathrm{mM}$ nonessential amino acids, and antibiotics. Peripheral blood or bone marrow from patients with AML were collected after obtaining informed consent as approved by the institutional review board of Northwestern University. Mononuclear cells were isolated following Histopaque density gradient separation (Sigma-Aldrich). For immunoblotting analysis the mononuclear cells were cultured overnight in IMDM medium supplemented with $20 \%$ FBS prior to drug treatment. SEL201 was provided by Selvita S. A. (Ryvu Therapeutics S. A.). 5'-azacytidine and rapamycin were purchased from Sigma-Aldrich (St. Louis, MO, USA).

\section{Cell lysis and immunoblotting}

For immunoblotting experiments, cells were treated with either vehicle-DMSO (control) or SEL201 at indicated doses and time points. Cells were lysed in lysis buffer (50 mM Hepes pH 7.3, $150 \mathrm{mM} \mathrm{NaCl}, 1.5$ $\mathrm{mM} \mathrm{MgCl}, 1 \mathrm{mM}$ EDTA pH 8.0, $100 \mu \mathrm{M} \mathrm{NaF}, 100$ $\mu \mathrm{M} \mathrm{Na} \mathrm{P}_{2} \mathrm{O}_{7}, 0.5 \%$ Triton $\mathrm{X}-100$, and $10 \%$ glycerol) supplemented with protease and phosphatase inhibitors. Equal amounts of total cell lysates were resolved by SDSPAGE and processed for immunoblotting essentially as in our previous studies $[54,55]$. Antibodies against phosphoeIF4E (Ser209) (\#9741), cleaved Caspase-3 (\#9661) Caspase 3 (\#9662), PARP (\#9542), were from Cell Signaling. Antibodies against eIF4E (sc-9976), HSP-90 (sc-7947) were from Santa Cruz Biotechnology, and antiGAPDH (\#374) antibody was purchased from Millipore.

\section{Cell viability assays}

Cell viability assays were performed as previously described using WST-1 Reagent (Sigma-Aldrich) $[46,56]$. For combination therapy, the effect of drug interaction on cell viability was measured by calculating the combination index (CI) using CompuSyn. The CI values were calculated as previously described [56].

\section{Clonogenic leukemic progenitor assays in methylcellulose}

This assay was performed as described in previous studies [46]. Peripheral blood was collected from patients with AML after obtained informed consent approved by the Northwestern University Institutional Review Board. To assess the effect of SEL201 on leukemic progenitor colony formation (CFU-L), mononuclear cells were plated in methylcellulose in the presence of vehicleDMSO (control) or increasing doses of SEL201 and the indicated agents. Human normal bone marrow $\mathrm{CD} 34^{+}$cells (ATCC) were used to assess CFU-GM colony formation in clonogenic assays in methylcellulose (Stemcell Technologies) in the presence or absence of SEL201 at the indicated doses.

\section{Analysis of apoptosis by flow cytometry}

MV4-11 and MM6 cells were treated with either vehicle-DMSO (control) or SEL201 at the indicated times and doses. U937 were treated with vehicle-DMSO (control) or SEL201 and/or 5'-azacytidine for 48 and 72 hours. Samples were processed and analyzed as previously described $[46,56]$.

\section{Statistical analysis}

All statistical analyses were performed using GraphPad Prism 6.0 software as described previously $[46,56]$.

\section{Abbreviations}

MAPK: mitogen-activated protein kinase; MNK: MAPK-interacting kinases; AML: acute myeloid leukemia; eIF4EL: eukaryotic translation initiation factor 4E; PARP: poly ADP ribose polymerase; mTORC1: mammalian target of rapamycin complex 1; MDS: myelodysplastic syndromes.

\section{Author contributions}

E.M.K., A.K., D.S., and L.C.P designed research; E.M.K., A.K., G.T.B., M.F., R.S., S.A., A.A.M. performed research, E.M.K., A.K., D.S., G.T.B., E.A.E., E.M.B., F.E., and L.C.P., analysed data/interpreted experimental results., T.R., K.B., provided key material., E.M.K., D.S., F.E., L.C.P., wrote/edited the manuscript. All authors read and approved the final manuscript.

\section{ACKNOWLEDGMENTS}

This work was supported by the Northwestern University - Flow Cytometry Core Facility supported by Cancer Center Support Grant (NCI CA060553). 


\section{CONFLICTS OF INTEREST}

T. Rzymski, K. Brzozka are employees of Ryvu Therapeutics and stockholders of Ryvu Therapeutics/ Selvita S.A. K. Brzozka is also a board member of Ryvu Therapeutics.

\section{FUNDING}

This work was supported by grant I01CX000916 from the Department of Veterans Affairs, grants R01CA121192, R01-CA77816 from the National Institutes of Health grants and by funds from the Vassilatos foundation.

\section{REFERENCES}

1. Gilliland DG, Jordan CT, Felix CA. The molecular basis of leukemia. Hematology (Am Soc Hematol Educ Program). 2004; 2004:80-97. https://doi.org/10.1182/ asheducation-2004.1.80. [PubMed]

2. Milella M, Kornblau SM, Estrov Z, Carter BZ, Lapillonne H, Harris D, Konopleva M, Zhao S, Estey E, Andreeff M. Therapeutic targeting of the MEK/MAPK signal transduction module in acute myeloid leukemia. J Clin Invest. 2001; 108:851-59. https://doi.org/10.1172/ JCI12807. [PubMed]

3. Platanias LC. Map kinase signaling pathways and hematologic malignancies. Blood. 2003; 101:4667-79. https://doi.org/10.1182/blood-2002-12-3647. [PubMed]

4. Raman M, Chen W, Cobb MH. Differential regulation and properties of MAPKs. Oncogene. 2007; 26:3100-12. https://doi.org/10.1038/sj.onc.1210392. [PubMed]

5. Sakamoto KM, Grant S, Saleiro D, Crispino JD, Hijiya N, Giles F, Platanias L, Eklund EA. Targeting novel signaling pathways for resistant acute myeloid leukemia. Mol Genet Metab. 2015; 114:397-402. https://doi.org/10.1016/j. ymgme.2014.11.017. [PubMed]

6. Kosciuczuk EM, Saleiro D, Platanias LC. Dual targeting of eIF4E by blocking MNK and mTOR pathways in leukemia. Cytokine. 2017; 89:116-21. https://doi.org/10.1016/j. cyto.2016.01.024. [PubMed]

7. Diab S, Kumarasiri M, Yu M, Teo T, Proud C, Milne R, Wang S. MAP kinase-interacting kinases - emerging targets against cancer. Chem Biol. 2014; 21:441-52. https://doi. org/10.1016/j.chembiol.2014.01.011. [PubMed]

8. Joshi S, Platanias LC. Mnk kinases in cytokine signaling and regulation of cytokine responses. Biomol Concepts. 2015; 6:85. https://doi.org/10.1515/bmc-2011-2000. [PubMed]

9. Korneeva NL, Song A, Gram H, Edens MA, Rhoads RE. Inhibition of Mitogen-activated Protein Kinase (MAPK)interacting Kinase (MNK) Preferentially Affects Translation of mRNAs Containing Both a 5'-Terminal Cap and Hairpin.
J Biol Chem. 2016; 291:3455-67. https://doi.org/10.1074/ ibc.M115.694190. [PubMed]

10. Mamane Y, Petroulakis E, Rong L, Yoshida K, Ler LW, Sonenberg N. eIF4E- from translation to transformation. Oncogene. 2004; 23:3172-79. https://doi.org/10.1038/ si.onc.1207549. [PubMed]

11. De Benedetti A, Graff JR. eIF-4E expression and its role in malignancies and metastases. Oncogene. 2004; 23:3189-99. https://doi.org/10.1038/sj.onc.1207545. [PubMed]

12. Waskiewicz AJ, Flynn A, Proud CG, Cooper JA. Mitogenactivated protein kinases activate the serine/threonine kinases Mnk1 and Mnk2. EMBO J. 1997; 16:1909-20. https://doi.org/10.1093/emboj/16.8.1909. [PubMed]

13. Wendel HG, Silva RL, Malina A, Mills JR, Zhu H, Ueda T, Watanabe-Fukunaga R, Fukunaga R, Teruya-Feldstein J, Pelletier J, Lowe SW. Dissecting eIF4E action in tumorigenesis. Genes Dev. 2007; 21:3232-37. https://doi. org $/ 10.1101 /$ gad.1604407. [PubMed]

14. Furic L, Rong L, Larsson O, Koumakpayi IH, Yoshida K, Brueschke A, Petroulakis E, Robichaud N, Pollak M, Gaboury LA, Pandolfi PP, Saad F, Sonenberg N. eIF4E phosphorylation promotes tumorigenesis and is associated with prostate cancer progression. Proc Natl Acad Sci USA. 2010; 107:14134-39. https://doi.org/10.1073/ pnas.1005320107. [PubMed]

15. Sonenberg N, Morgan MA, Merrick WC, Shatkin AJ. A polypeptide in eukaryotic initiation factors that crosslinks specifically to the 5'-terminal cap in mRNA. Proc Natl Acad Sci USA. 1978; 75:4843-47. https://doi.org/10.1073/ pnas.75.10.4843. [PubMed]

16. Ruggero D, Montanaro L, Ma L, Xu W, Londei P, CordonCardo C, Pandolfi PP. The translation factor eIF-4E promotes tumor formation and cooperates with $\mathrm{c}-\mathrm{Myc}$ in lymphomagenesis. Nat Med. 2004; 10:484-86. https://doi. org/10.1038/nm1042. [PubMed]

17. De Benedetti A, Harris AL. eIF4E expression in tumors: its possible role in progression of malignancies. Int $\mathrm{J}$ Biochem Cell Biol. 1999; 31:59-72. https://doi.org/10.1016/S13572725(98)00132-0. [PubMed]

18. Heikkinen T, Korpela T, Fagerholm R, Khan S, Aittomäki $\mathrm{K}$, Heikkilä P, Blomqvist C, Carpén O, Nevanlinna H. Eukaryotic translation initiation factor 4E (eIF4E) expression is associated with breast cancer tumor phenotype and predicts survival after anthracycline chemotherapy treatment. Breast Cancer Res Treat. 2013; 141:79-88. https://doi.org/10.1007/s10549-013-2671-2. [PubMed]

19. Graff JR, Konicek BW, Lynch RL, Dumstorf CA, Dowless MS, McNulty AM, Parsons SH, Brail LH, Colligan BM, Koop JW, Hurst BM, Deddens JA, Neubauer BL, et al. eIF4E activation is commonly elevated in advanced human prostate cancers and significantly related to reduced patient survival. Cancer Res. 2009; 69:3866-73. https://doi. org/10.1158/0008-5472.CAN-08-3472. [ PubMed] 
20. Martinez-Marignac V, Shawi M, Pinedo-Carpio E, Wang X, Panasci L, Miller W, Pettersson F, Aloyz R. Pharmacological targeting of eIF4E in primary CLL lymphocytes. Blood Cancer J. 2013; 3:e146. https://doi. org/10.1038/bcj.2013.43. [PubMed]

21. Topisirovic I, Ruiz-Gutierrez M, Borden KL. Phosphorylation of the eukaryotic translation initiation factor eIF4E contributes to its transformation and mRNA transport activities. Cancer Res. 2004; 64:8639-42. https:// doi.org/10.1158/0008-5472.CAN-04-2677. [PubMed]

22. Ueda T, Sasaki M, Elia AJ, Chio II, Hamada K, Fukunaga R, Mak TW. Combined deficiency for MAP kinaseinteracting kinase 1 and 2 (Mnk1 and Mnk2) delays tumor development. Proc Natl Acad Sci USA. 2010; 107:13984 90. https://doi.org/10.1073/pnas.1008136107. [PubMed]

23. Ueda T, Watanabe-Fukunaga R, Fukuyama H, Nagata S, Fukunaga R. Mnk2 and Mnk1 are essential for constitutive and inducible phosphorylation of eukaryotic initiation factor $4 \mathrm{E}$ but not for cell growth or development. Mol Cell Biol. 2004; 24:6539-49. https://doi.org/10.1128/ MCB.24.15.6539-6549.2004. [PubMed]

24. Robichaud N, del Rincon SV, Huor B, Alain T, Petruccelli LA, Hearnden J, Goncalves C, Grotegut S, Spruck CH, Furic L, Larsson O, Muller WJ, Miller WH, Sonenberg N. Phosphorylation of eIF4E promotes EMT and metastasis via translational control of SNAIL and MMP-3. Oncogene. 2015; 34:2032-42. https://doi.org/10.1038/onc.2014.146. [PubMed]

25. Zhan Y, Guo J, Yang W, Goncalves C, Rzymski T, Dreas A, Żyłkiewicz E, Mikulski M, Brzózka K, Golas A, Kong Y, Ma M, Huang F, et al. MNK1/2 inhibition limits oncogenicity and metastasis of KIT-mutant melanoma. J Clin Invest. 2017; 127:4179-92. https://doi.org/10.1172/ JCI91258. [PubMed]

26. Guo Q, Li VZ, Nichol JN, Huang F, Yang W, Preston SE, Talat Z, Lefrère H, Yu H, Zhang G, Basik M, Gonçalves C, Zhan $\mathrm{Y}$, et al. MNK1/NODAL signaling promotes invasive progression of breast ductal carcinoma in situ. Cancer Res. 2019; 79:1646-57. https://doi.org/10.1158/0008-5472. CAN-18-1602. [PubMed]

27. Hanahan D, Weinberg RA. Hallmarks of cancer: the next generation. Cell. 2011; 144:646-74. https://doi. org/10.1016/j.cell.2011.02.013. [PubMed]

28. Watts J, Nimer S. Recent advances in the understanding and treatment of acute myeloid leukemia. F1000 Res. 2018; 7:F1000 Faculty Rev-1196. https://doi.org/10.12688/ f1000research.14116.1. [PubMed]

29. Mangan JK, Luger SM. Salvage therapy for relapsed or refractory acute myeloid leukemia. Ther Adv Hematol. 2011; 2:73-82. https://doi.org/10.1177/2040620711402533. [PubMed]

30. Altman JK, Szilard A, Konicek BW, Iversen PW, Kroczynska B, Glaser H, Sassano A, Vakana E, Graff JR, Platanias LC. Inhibition of Mnk kinase activity by cercosporamide and suppressive effects on acute myeloid leukemia precursors. Blood. 2013; 121:3675-81. https://doi. org/10.1182/blood-2013-01-477216. [PubMed]

31. Altman JK, Glaser H, Sassano A, Joshi S, Ueda T, Watanabe-Fukunaga R, Fukunaga R, Tallman MS, Platanias LC. Negative regulatory effects of Mnk kinases in the generation of chemotherapy-induced antileukemic responses. Mol Pharmacol. 2010; 78:778-84. https://doi. org/10.1124/mol.110.064642. [PubMed]

32. Teo T, Yu M, Yang Y, Gillam T, Lam F, Sykes MJ, Wang S. Pharmacologic co-inhibition of Mnks and mTORC1 synergistically suppresses proliferation and perturbs cell cycle progression in blast crisis-chronic myeloid leukemia cells. Cancer Lett. 2015; 357:612-23. https://doi. org/10.1016/j.canlet.2014.12.029. [PubMed]

33. Eckerdt F, Beauchamp E, Bell J, Iqbal A, Su B, Fukunaga R, Lulla RR, Goldman S, Platanias LC. Regulatory effects of a Mnk2-eIF4E feedback loop during mTORC1 targeting of human medulloblastoma cells. Oncotarget. 2014; 5:844251. https://doi.org/10.18632/oncotarget.2319. [PubMed]

34. Janes MR, Limon JJ, So L, Chen J, Lim RJ, Chavez MA, Vu C, Lilly MB, Mallya S, Ong ST, Konopleva M, Martin MB, Ren P, et al. Effective and selective targeting of leukemia cells using a TORC1/2 kinase inhibitor. Nat Med. 2010; 16:205-13. https://doi.org/10.1038/nm.2091. [PubMed]

35. Schuh AC, Döhner H, Pleyer L, Seymour JF, Fenaux P, Dombret H. Azacitidine in adult patients with acute myeloid leukemia. Crit Rev Oncol Hematol. 2017; 116:159-77. https://doi.org/10.1016/j.critrevonc.2017.05.010. [PubMed]

36. Roboz GJ, Montesinos P, Selleslag D, Wei A, Jang JH, Falantes J, Voso MT, Sayar H, Porkka K, Marlton P, Almeida A, Mohan S, Ravandi F, et al. Design of the randomized, Phase III, QUAZAR AML Maintenance trial of CC-486 (oral azacitidine) maintenance therapy in acute myeloid leukemia. Future Oncol. 2016; 12:293-302. https:// doi.org/10.2217/fon.15.326. [PubMed]

37. Towatari M, Iida H, Tanimoto M, Iwata H, Hamaguchi M, Saito H. Constitutive activation of mitogen-activated protein kinase pathway in acute leukemia cells. Leukemia. 1997; 11:479-84. https://doi.org/10.1038/sj.leu.2400617. [PubMed]

38. Landon AL, Muniandy PA, Shetty AC, Lehrmann E, Volpon L, Houng S, Zhang Y, Dai B, Peroutka R, Mazan-Mamczarz K, Steinhardt J, Mahurkar A, Becker KG, et al. MNKs act as a regulatory switch for eIF4E1 and eIF4E3 driven mRNA translation in DLBCL. Nat Commun. 2014; 5:5413. https:// doi.org/10.1038/ncomms6413. [PubMed]

39. Malina A, Cencic R, Pelletier J. Targeting translation dependence in cancer. Oncotarget. 2011; 2:76-88. https:// doi.org/10.18632/oncotarget.218. [PubMed]

40. Lim S, Saw TY, Zhang M, Janes MR, Nacro K, Hill J, Lim AQ, Chang CT, Fruman DA, Rizzieri DA, Tan SY, Fan H, Chuah CT, Ong ST. Targeting of the MNK-eIF4E axis in blast crisis chronic myeloid leukemia inhibits leukemia stem cell function. Proc Natl Acad Sci USA. 2013; 
110:E2298-307. https://doi.org/10.1073/pnas.1301838110. [PubMed]

41. Topisirovic I, Guzman ML, McConnell MJ, Licht JD, Culjkovic B, Neering SJ, Jordan CT, Borden KL. Aberrant eukaryotic translation initiation factor 4E-dependent mRNA transport impedes hematopoietic differentiation and contributes to leukemogenesis. Mol Cell Biol. 2003; 23:8992-9002. https://doi.org/10.1128/MCB.23.24.89929002.2003. [PubMed]

42. Assouline S, Culjkovic B, Cocolakis E, Rousseau C, Beslu N, Amri A, Caplan S, Leber B, Roy DC, Miller WH Jr, Borden KL. Molecular targeting of the oncogene eIF4E in acute myeloid leukemia (AML): a proof-of-principle clinical trial with ribavirin. Blood. 2009; 114:257-60. https://doi.org/10.1182/blood-2009-02-205153. [PubMed]

43. Graff JR, Konicek BW, Vincent TM, Lynch RL, Monteith D, Weir SN, Schwier P, Capen A, Goode RL, Dowless MS, Chen Y, Zhang H, Sissons S, et al. Therapeutic suppression of translation initiation factor eIF4E expression reduces tumor growth without toxicity. J Clin Invest. 2007; 117:2638-48. https://doi.org/10.1172/JCI32044. [PubMed]

44. Hong DS, Kurzrock R, Oh Y, Wheler J, Naing A, Brail L, Callies S, André V, Kadam SK, Nasir A, Holzer TR, Meric-Bernstam F, Fishman M, Simon G. A phase 1 dose escalation, pharmacokinetic, and pharmacodynamic evaluation of eIF-4E antisense oligonucleotide LY2275796 in patients with advanced cancer. Clin Cancer Res. 2011; 17:6582-91. https://doi.org/10.1158/1078-0432.CCR-110430. [PubMed]

45. Duffy AG, Makarova-Rusher OV, Ulahannan SV, Rahma OE, Fioravanti S, Walker M, Abdullah S, Raffeld M, Anderson V, Abi-Jaoudeh N, Levy E, Wood BJ, Lee S, et al. Modulation of tumor eIF4E by antisense inhibition: A phase I/II translational clinical trial of ISIS 183750-an antisense oligonucleotide against eIF4E-in combination with irinotecan in solid tumors and irinotecan-refractory colorectal cancer. Int J Cancer. 2016; 139:1648-57. https:// doi.org/10.1002/ijc.30199. [PubMed]

46. Kosciuczuk EM, Saleiro D, Kroczynska B, Beauchamp EM, Eckerdt F, Blyth GT, Abedin SM, Giles FJ, Altman JK, Platanias LC. Merestinib blocks Mnk kinase activity in acute myeloid leukemia progenitors and exhibits antileukemic effects in vitro and in vivo. Blood. 2016;

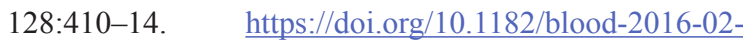
698704. [PubMed]

47. Konicek BW, Stephens JR, McNulty AM, Robichaud N, Peery RB, Dumstorf CA, Dowless MS, Iversen PW, Parsons S, Ellis KE, McCann DJ, Pelletier J, Furic L, et al. Therapeutic inhibition of MAP kinase interacting kinase blocks eukaryotic initiation factor 4E phosphorylation and suppresses outgrowth of experimental lung metastases. Cancer Res. 2011; 71:1849-57. https://doi. org/10.1158/0008-5472.CAN-10-3298. [PubMed]
48. Bell JB, Eckerdt F, Dhruv HD, Finlay D, Peng S, Kim S, Kroczynska B, Beauchamp EM, Alley K, Clymer J, Goldman S, Cheng SY, James CD, et al. Differential response of glioma stem cells to arsenic trioxide therapy is regulated by MNK1 and mRNA translation. Mol Cancer Res. 2018; 16:32-46. https://doi.org/10.1158/1541-7786. MCR-17-0397. [PubMed]

49. D’Abronzo LS, Bose S, Crapuchettes ME, Beggs RE, Vinall RL, Tepper CG, Siddiqui S, Mudryj M, Melgoza FU, Durbin-Johnson BP, deVere White RW, Ghosh PM. The androgen receptor is a negative regulator of eIF4E phosphorylation at S209: implications for the use of mTOR inhibitors in advanced prostate cancer. Oncogene. 2017; 36:6359-73. https://doi.org/10.1038/onc.2017.233. [PubMed]

50. Lineham E, Tizzard GJ, Coles SJ, Spencer J, Morley SJ. Synergistic effects of inhibiting the MNK-eIF4E and PI3K/ AKT/ mTOR pathways on cell migration in MDA-MB-231 cells. Oncotarget. 2018; 9:14148-59. https://doi. org/10.18632/oncotarget.24354. [PubMed]

51. Pleyer L, Greil R. Digging deep into "dirty" drugs modulation of the methylation machinery. Drug Metab Rev. 2015; 47:252-279. https://doi.org/10.3109/03602532.2014. 995379. [PubMed]

52. Döhner H, Dolnik A, Tang L, Seymour JF, Minden MD, Stone RM, Del Castillo TB, Al-Ali HK, Santini V, Vyas P, Beach CL, MacBeth KJ, Skikne BS, et al. Cytogenetics and gene mutations influence survival in older patients with acute myeloid leukemia treated with azacitidine or conventional care. Leukemia. 2018; 32:2546-57. https:// doi.org/10.1038/s41375-018-0257-z. [PubMed]

53. Kraljacic BC, Arguello M, Amri A, Cormack G, Borden K. Inhibition of eIF4E with ribavirin cooperates with common chemotherapies in primary acute myeloid leukemia specimens. Leukemia. 2011; 25:1197-200. https://doi. org/10.1038/leu.2011.57. [PubMed]

54. Saleiro D, Mehrotra S, Kroczynska B, Beauchamp EM, Lisowski P, Majchrzak-Kita B, Bhagat TD, Stein BL, McMahon B, Altman JK, Kosciuczuk EM, Baker DP, Jie $\mathrm{C}$, et al. Central role of ULK1 in type I interferon signaling. Cell Reports. 2015; 11:605-17. https://doi.org/10.1016/j. celrep.2015.03.056. [PubMed]

55. Kroczynska B, Kaur S, Katsoulidis E, Majchrzak-Kita B, Sassano A, Kozma SC, Fish EN, Platanias LC. Interferondependent engagement of eukaryotic initiation factor 4B via S6 kinase (S6K)- and ribosomal protein S6K-mediated signals. Mol Cell Biol. 2009; 29:2865-75. https://doi. org/10.1128/MCB.01537-08. [PubMed]

56. Colamonici M, Blyth G, Saleiro D, Szilard A, Bliss-Moreau M, Giles FJ, Altman JK, Beauchamp EM, Platanias LC. Dual targeting of acute myeloid leukemia progenitors by catalytic mTOR inhibition and blockade of the p110 $\alpha$ subunit of PI3 kinase. Oncotarget. 2015; 6:8062-70. https:// doi.org/10.18632/oncotarget.3509. [PubMed] 